\title{
EFEKTIVITAS PROBLEM SOLVING DAN PROBLEM POSING TERHADAP KEMAMPUAN KOMUNIKASI MATEMATIS SISWA KELAS VII SMPN 47 BATAM
}

\section{EFFECTIVENESS OF PROBLEM SOLVING AND PROLEM POSING TOWARD OF STUDENT'S MATHEMATICS COMMUNICATION ABILITIES IN THE VII CLASS SMPN 47 BATAM}

\author{
Era Rianti ${ }^{1}$, Fitrah Amelia ${ }^{2}$ \\ Program Studi Pendidikan Matematika, Fakultas Keguruan dan Ilmu Pendidikan \\ Universitas Riau Kepulauan, Batam, Kepulauan Riau, Indonesia \\ ${ }^{2}$ e-mail:fitrahamelia@yahoo.com
}

\begin{abstract}
ABSTRAK
Penelitian ini bertujuan untuk: (1). Mengetahui keefektifan model pembelajaran problem solving terhadap kemampuan komunikasi matematis siswa, (2). Mengetahui keefektifan model pembelajaran problem posing terhadap kemampuan komunikasi matematis siswa, (3). Mengetahui perbedaan keefektifan model pembelajaran problem solving dan problem posing terhadap kemampuan komunikasi matematis siswa. Penelitian ini menggunakan metode quasi eksperimen. Populasi dalam penelitian ini adalah siswa kelas VII SMP Negeri 47 Batam, teknik pengambilan sampel menggunakan purposive sampling. Alat pengumpulan data yang digunakan berupa tes yang diberikan di akhir perlakuan. Tes yang diberikan adalah tes tertulis berbentuk soal essay. Dari penelitian didapat hasil bahwa: (1). Model pembelajaran problem solving tidak efektif terhadap kemampuan komunikasi matematis siswa, (2). Model pembelajaran problem posing efektif terhadap kemampuan komunikasi matematis siswa (3). Tidak terdapat perbedaan keefektifan antara model pembelajaran problem solving dan problem posing terhadap kemampuan komunikasi matematis
\end{abstract}

Kata Kunci: Model pembelajaran problem solving, model pembelajaran problem posing, dan kemampuan komunikasi matematis

\section{ABSTRACT}

This research aims to: (1). Knowing the effectiveness of the learning model problem solving toward of student's mathematics communication abilities, (2). Knowing the effectiveness of the learning model problem posing toward of student's mathematics communication abilities, (3). Knowing the difference between the effectivenees of the learning model problem solving and problem posing toward of student's mathematics communication abilities. The experiment was using quasi-experiment methode. Population in this research were students of grade $7^{\text {th }}$ SMPN 47 Batam, a sampling technique that uses purposive sampling. Instrument in this research a essay test. The results show that: (1). The learning model problem solving not effectively toward of student's mathematics communication abilities, (2). The learning model problem posing effectively toward of student's mathematics communication abilities, (3). There is no difference in effectiveness between the learning model of problem solving and problem posing toward of student's mathematics communication abilities.

Keywords: problem solving learning model, problem posing learning model, and mathematics communication abilities

\section{PENDAHULUAN}

Tujuan pembelajaran matematika yang dirumuskan oleh National Council of Teacher of Mathematics (NCTM, 2000) yaitu: (1) belajar untuk berkomunikasi, (2) belajar untuk bernalar , (3) belajar untuk memecahkan masalah, (4) belajar untuk mengaitkan ide, (5) pembentukan sikap positif terhadap matematika. Dari tujuan pembelajaran matematika tersebut salah satunya adalah 
untuk meningkatkan kemampuan komunikasi matematis siswa. Komunikasi matematis merupakan bagian penting dalam pembelajaran matematika. Hal ini mengisyaratkan bahwa kemampuan komunikasi matematis harus dikuasai oleh siswa. Hal ini berbeda dengan kenyataan yang terjadi di SMP 47 Batam. Kemampuan komunikasi matematis sebagian siswa di SMP Negeri 47 Batam masih tergolong rendah. Hal tersebut dinyatakan oleh salah satu guru matematika kelas VII yang mengatakan bahwa "Sebagian siswa kelas VII masih merasa sulit untuk menyampaikan ide matematika ke dalam bentuk atau simbol matematika dalam kehidupan sehari-hari, selain itu juga ketika ditanya siswa masih diam saja”. Ketika ditanya penyebab utama rendahnya komunikasi matematis siswa, guru kelas VII ini mengemukakan bahwa "Siswa masih kurang paham terhadap suatu konsep matematika, hal ini tampak bahwa sebagian besar siswa masih kesulitan dalam menyelesaikan suatu permasalahan yang diberikan dalam bentuk soal uraian dan tahap penyelesaian dari soal tersebut, ketika dihadapkan pada soal cerita, siswa tidak terbiasa dan sering lupa untuk menuliskan apa yang diketahui, ditanyakan, dan dijawab dari soal sebelum menyelesaikannya, sehingga siswa sering salah dalam memahami maksud dari soal tersebut, latihan-latihan yang diberikan belum dapat membuat siswa mengembangkan ide-ide matematikanya". Hal ini dapat terlihat pada hasil kemampuan komunikasi matematis siswa berikut ini:

Tabel 1. Hasil Persentase Kemampuan Komunikasi Matematis

\begin{tabular}{llllll}
\hline Kelas & $\begin{array}{l}\text { Jumlah } \\
\text { Siswa }\end{array}$ & KKM & $\begin{array}{l}\text { Jumlah } \\
\text { Memenuhi } \\
\text { KKM }\end{array}$ & $\begin{array}{l}\text { Jumlah } \\
\text { dibawah KKM }\end{array}$ & $\begin{array}{l}\text { Persentase } \\
\text { Ketuntasan (\%) }\end{array}$ \\
\hline $\mathrm{VII}_{1}$ & 45 & 70 & 15 & 30 & 33 \\
$\mathrm{VII}_{2}$ & 47 & 70 & 7 & 40 & 15 \\
$\mathrm{VII}_{3}$ & 47 & 70 & 10 & 37 & 21 \\
$\mathrm{VII}_{4}$ & 43 & 70 & 11 & 32 & 26 \\
$\mathrm{VII}_{5}$ & 44 & 70 & 9 & 35 & 20 \\
$\mathrm{VII}_{6}$ & 46 & 70 & 13 & 33 & 28 \\
\hline
\end{tabular}

Sumber: Guru Matematika Kelas VII SMPN 47 Batam

Berdasarkan tabel diatas terlihat bahwa kemampuan komunikasi matematis siswa masih rendah yaitu masih dibawahh 50\%. Hal ini dikarenakan pada saat proses belajar mengajar berlangsung siswa kurang aktif dan kreatif di dalam kelas, sehingga kelas menjadi jenuh dan membosankan. 
Kondisi di atas terjadi dalam pembelajaran matematika secara konvensional, siswa jarang sekali diminta untuk mengkomunikasikan ide-idenya. Kondisi pembelajaran yang menempatkan siswa sebagai subjek pasif, jelas tidak menguntungkan terhadap hasil belajarnya. Untuk itu perlu usaha guru agar siswa belajar secara aktif. Salah satu usaha yang dapat dilakukan dalam pelaksanaan pembelajaran, guru dapat mengakomodasi dan memfasilitasi ide siswa sehingga siswa dapat mengilustrasikan dan menginterpretasikan berbagai masalah dalam bahasa dan pernyataan-pernyataan matematika serta dapat menyelesaikan masalah tersebut menurut aturan atau kaedah matematika. Kemampuan siswa mengilustrasikan dan menginterprestasikan berbagai masalah dalam bahasa dan pernyataan-pernyataan matematika serta dapat menyelesaikan masalah tersebut menurut aturan atau kaedah matematika, merupakan karakteristik siswa yang mempunyai kemampuan komunikasi matematis.

Untuk meningkatkan kemampuan komunikasi matematis siswa, dibutuhkan suatu model pembelajaran yang mampu memberikan kemudahan belajar bagi siswa. Implikasi terhadap pembelajaran adalah bahwa kegiatan pembelajaran identik dengan aktivitas siswa secara optimal. Oleh karena itu alternatif yang dapat menjadi pilihan guru dalam proses pembelajaran matematika untuk memicu komunikasi matematis antar siswa dan guru yaitu dengan model pembelajaran Problem Solving dan Problem Posing.

Problem Solving merupakan model pembelajaran yang merangsang siswa untuk mau berfikir, menganalisa suatu permasalahan sehingga dapat menentukan pemecahannya. Hal ini sejalan dengan pendapat (Suhendri \& Mardalena, n.d; Sutikno, 2014) yang mengatakan bahwa model pembelajaran pemecahan masalah (problem solving) merupakan model pembelajaran yang mengandung aktivitas belajar siswa cukup tinggi, sebagai suatu proses mental dan intelektual dalam menemukan suatu masalah dan memecahkannya berdasarkan data dan informasi yang akurat sehingga dapat diambil simpulan yang tepat dan cermat. Problem Solving digunakan untuk mendukung pelaksanaan pembelajaran. Hal ini dilaksanakan sebagai upaya pembaharuan kurikulum pendidikan nasional. Dengan adanya Problem Solving siswa tidak hanya menerima hafalan yang diberikan guru, tetapi siswa menemukan dan membangun sendiri konsep yang dipelajari, siswa dibiasakan mandiri, berfikir kritis dan kreatif, bekerjasama secara positif, dan dapat mengkomunikasikan dengan baik penyelesaian yang telah diperoleh.

Problem Posing merupakan model pembelajaran yang mengharuskan siswa menyusun pertanyaan sendiri atau memecah suatu soal menjadi pertanyaan-pertanyaan yang lebih 
sederhana (Shoimin, 2016). Problem Posing digunakan untuk mengoptimalkan aktifitas siswa dalam pembelajaran. Dalam Problem Posing, siswa tidak hanya diminta untuk membuat soal atau mengajukan suatu pertanyaan, tetapi mencari penyelesaiannya. Penyelesaian dari soal yang mereka buat bisa dikerjakan sendiri, meminta tolong teman, atau dikerjakan secara kelompok. Dengan demikian siswa dapat menyelesaikan masalah tersebut dengan baik dan dapat mengkomunikasikan di depan kelas.

Komunikasi matematis adalah kemampuan untuk berkomunikasi yang meliputi kegiatan penggunaan keahlian menulis, menyimak, menelaah, menginterpretasikan, dan mengevaluasi ide, simbol, istilah, serta informasi matematika yang diamati melalui proses mendengar, mempresentasi, dan diskusi (Ramdani, 2012).

Berdasarkan uraian di atas jelas bahwa kemampuan komunikasi matematis siswa perlu mendapat perhatian untuk lebih dikembangkan. Peneliti berharap model pembelajaran Problem Solving dan Problem Posing dapat menjadi salah satu model pembelajaran alternatif yang dapat dipilih oleh guru agar menjadikan siswa aktif berkomunikasi di dalam kelas, sehingga kemampuan komunikasi matematis siswa menjadi maksimal. Oleh karena itu peneliti tertarik untuk mengkaji permasalahan tersebut dengan memberi judul "Efektivitas Model Pembelajaran Problem Solving dan Problem Posing terhadap Kemampuan Komunikasi Matematis Siswa Kelas VII SMPN 47 Batam".

\section{METODOLOGI (Material dan Metode)}

Metode penelitian ini merupakan metode quasi eksperimen (eksperimen semu). Sedangkan jenis penelitian ini adalah penelitian komparatif. Penelitian ini dilakukan untuk mengetahui perbedaan keefektifan antara model pembelajaran problem solving dengan model pembelajaran problem posing terhadap kemampuan komunikasi matematis siswa di kelas VII SMPN 47 Batam dengan desain penelitian menggunakan Posttest-Only Control Design. Penelitian dilakukan di dua kelas, yaitu kelas eksperimen 1 dan kelas eksperimen 2. populasi yang diambil dalam penelitian ini adalah seluruh siswa kelas VII SMP Negeri 47 Batam yang terdiri dari 6 kelas. Teknik sampling yang digunakan yaitu teknik sampling bertujuan (Purposive Sampling). Pemilihan sampel dilakukan dengan teknik ini karena kelas yang diampu atau diajar oleh guru yang sama dan berdasarkan pertimbangan guru bidang studi matematika yang mengajar kelas 
tersebut melihat bahwa penyebaran siswa di kedua kelas yang dipilih sebagai sampel merata secara akademik.

Mengingat jenis dari penelitian ini adalah penelitian komparatif, maka dibutuhkan setidaknya 2 kelas untuk mengisi sampel penelitiannya. Kelas tersebut dibagi menjadi kelas eksperimen 1 dan kelas eksperimen 2. Adapun kelas eksperimen 1 yaitu kelas VII $_{1}$ yang mendapat perlakuan model pembelajaran problem solving. Sementara yang menjadi kelas eksperimen 2 adalah kelas $\mathrm{VII}_{3}$ yang mendapatkan perlakuan model pembelajaran problem posing.

\section{PEMBAHASAN}

\section{Deskripsi data}

Deskripsi kemampuan komunikasi matematis siswa kelas eksperimen 1 dan kelas eksperimen 2 dapat dilihat pada Tabel 2 berikut:

Tabel 2. Deskripsi Hasil Kemampuan Komunikasi Matematis Siswa Kelas Eksperimen 1 dan Kelas Eksperimen 2

\begin{tabular}{llll}
\hline No & Deskripsi Data & Kelas Eksperimen 1 & Kelas Eksperimen 2 \\
\hline 1 & Mean & 70,533 & 74,021 \\
2 & Standar Deviasi & 11,847 & 11,652 \\
3 & Varians & 140,351 & 135,769 \\
4 & Nilai Maksimum & 92 & 98 \\
5 & Nilai Minimum & 45 & 43 \\
\hline
\end{tabular}

\section{Uji Keseimbangan Rata-rata}

Dalam penelitian ini, uji keseimbangan rata-rata digunakan untuk mengetahui kemampuan awal komunikasi matematis siswa menggunakan rumus polled varian. Sebelum melakukan perhitungan dengan menggunakan rumus polled varian akan dilakukan uji normalitas dan uji homogenitas terlebih dahulu.

Uji normalitas dilakukan pada data hasil Ulangan Harian dari siswa kelas eksperimen 1 dan kelas eksperimen 2 dengan menggunakan uji chi kuadrat $\left(\chi^{2}\right)$ dengan $\mathrm{db}=\mathrm{k}-3$ dan taraf signifikansi $(\alpha)=0,05$. Berdasarkan hasil perhitungan dengan menggunakan uji chi kuadrat $\left(\chi^{2}\right)$

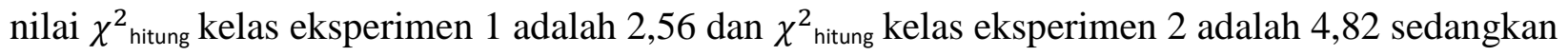
$\chi^{2}{ }_{\text {tabel }}$ kelas eksperimen 1 adalah 7,82 dan $\chi^{2}$ tabel kelas eksperimen 2 adalah 9,49 dengan demikian 
dapat dikatakan bahwa kelas eksperimen 1 dan kelas eksperimen 2 sampel berdistribusi normal karena $\chi^{2}{ }_{\text {hitung }}<\chi^{2}$ tabel untuk kedua kelas sampel.

Uji homogenitas yang dilakukan yaitu uji varians terbesar dibanding dengan uji varians terkecil hal ini dilakukan untuk mengetahui data yang dibandingkan dalam hal ini adalah data hasil Ulangan Harian kelas eksperimen 1 dan kelas eksperimen 2 homogen atau tidak. Berdasarkan hasil perhitungan dengan varians kelas eksperimen 1 adalah 244,710 dan varians kelas eksperimen 2 adalah 165,647 didapat $F_{\text {hitung }}=1,477$ dan $F_{\text {tabel }}(44,46)$ dengan taraf signifikansi $(\alpha)=0,05$ adalah 1,639 maka $F_{\text {hitung }} \leq F_{\text {tabel }}$ sehingga varians kedua sampel homogen.

Setelah diketahui data berdistribusi normal dan homogen, selanjutnya adalah membuktikan hipotesis dengan menggunakan uji $\mathrm{t}$ dua sampel polled varian. Dengan $\mathrm{dk}=n_{1}+n_{2}-2=$ $45+47-2=90$ dan taraf signifikan $5 \%$, maka $t_{\text {tabel }}=1,986$ dan $t_{\text {hitung }}=-0,604$ maka diperoleh kesimpulan $-t_{\text {tabel }}(-1,986) \leq t_{\text {hitung }}(-0,604) \leq t_{\text {tabel }}(1,986)$ hal ini berarti Ho diterima yaitu kedua kelas mempunyai kemampuan awal komunikasi matematis yang sama.

\section{Uji prasyarat}

Uji normalitas dilakukan pada data hasil Posttest dari siswa kelas eksperimen 1 dan kelas eksperimen 2 dengan menggunakan uji chi kuadrat $\left(\chi^{2}\right)$. Berdasarkan hasil perhitungan dengan menggunakan uji chi kuadrat $\left(\chi^{2}\right)$ nilai $\chi^{2}{ }_{\text {hitung }}$ kelas eksperimen 1 adalah 1,38 dan $\chi^{2}{ }_{\text {hitung }}$ kelas eksperimen 2 adalah 7,62 sedangkan $\chi^{2}$ tabel kelas eksperimen 1 adalah 7,82 dan $\chi_{\text {tabel kelas }}^{2}$ eksperimen 2 adalah 9,49 dengan demikian dapat dikatakan bahwa kelas eksperimen 1 dan kelas eksperimen 2 sampel berdistribusi normal karena $\chi^{2}$ hitung $<\chi_{\text {tabel }}^{2}$ untuk kedua kelas sampel.

Uji homogenitas yang digunakan adalah uji varians terbesar dibanding dengan uji varians terkecil hal ini dilakukan untuk mengetahui data yang dibandingkan dalam hal ini adalah data Posttest kelas eksperimen 1 dan kelas eksperimen 2 homogen atau tidak. Berdasarkan hasil perhitungan dengan varians kelas eksperimen 1 adalah 140,345 dan varians kelas eksperimen 2 adalah 135,760 didapat $F_{\text {hitung }}=1,034$ dan $F_{\text {tabel }}(44,46)$ dengan taraf signifikansi $(\alpha)=0,05$ adalah 1,639 maka $F_{\text {hitung }} \leq \mathrm{F}_{\text {tabel }}$ sehingga varians kedua sampel homogen.

\section{Hasil Uji Hipotesis}

Setelah diketahui data berdistribusi normal dan homogen, selanjutnya adalah membuktikan hipotesis penelitian dengan menggunakan uji t. Uji t yang digunakan adalah uji t satu sampel 
untuk pengujian hipotesis 1 dan 2 serta uji t dua sampel untuk pengujian hipotesis 3 . Hasil perhitungan $t_{\text {hitung }}$ dan $\mathrm{t}_{\text {tabel }}$ pada masing-masing hipotesis dapat dilihhat pada Tabel 3 berikut.

Tabel 3. Hasil perhitungan $t_{\text {hitung }}$ dan $t_{\text {tabel }}$ pada masing-masing hipotesis

\begin{tabular}{lllll}
\hline No & & \multicolumn{1}{c}{$\boldsymbol{t}_{\text {hitung }}$} & \multicolumn{1}{c}{$\boldsymbol{t}_{\text {tabel }}$} & Kesimpulan \\
\hline 1. & Hipotesis 1 & 0,302 & 2,015 & Ho diterima \\
2. & Hipotesis 2 & 2,366 & 2,013 & Ha diterima \\
3. & Hipotesis 3 & $-1,424$ & 1,986 & Ho diterima \\
\hline
\end{tabular}

Dari tabel di atas untuk hipotesis 1 dapat disimpulkan bahwa Ho diterima, itu berarti model pembelajaran Problem Solving tidak efektif dan signifikan terhadap kemampuan komunikasi matematis siswa. Selanjutnya untuk hipotesis 2 diperoleh kesimpulan Ha diterima artinya model pembelajaran problem posing efektif dan signifikan terhadap kemampuan komunikasi matematis siswa sedangan. Sedangkan untuk hipotessis 3 diperoleh kesimpulan Ho diterima artinya tidak terdapat perbedaan keefektifan dan signifikan antara model pembelajaran problem solving dan problem posing terhadap kemampuan komunikasi matematis siswa

\section{Pembahasan}

Kelas eksperimen 1 merupakan kelas yang menerapkan model pembelajaran Problem Solving. Penerapan model pembelajaran Problem Solving di kelas ini menunjukkan kemampuan komunikasi matematis yang baik. Hal tersebut juga terlihat dari kemampuan komunikasi matematis siswa berdasarkan rata-rata nilai ulangan harian dalam bentuk soal esay yang mengandung indikator kemampuan komunikasi matematis yang diperoleh dari guru matematika SMP Negeri 47 Batam sebesar 59,711 kemudian setelah mendapatkan perlakuan pembelajaran dengan model pembelajaran Problem Solving meningkat menjadi 70,533 melebihi KKM yaitu 70 yang kemudian dibuktikan melalui uji-t satu sampel. Menurut hasil perhitungan diperoleh hasil $t_{\text {hitung }}(0,302) \leq t_{\text {tabel }}(2,015)$. Hasil tersebut membuktikan bahwa penerapan model pembelajaran Problem Solving tidak efektif terhadap kemampuan komunikasi matematis siswa kelas VII SMP Negeri 47 Batam. Namun pada kenyataannya rata-rata kemampuan komunikasi matematis sebelum diberikan perlakuan dengan setelah diberikan perlakuan sangat jauh berbeda berdasarkan data yang diperoleh, karena setelah di berikan perlakuan dengan menggunakan model pembelajaran Problem Solving rata-rata kemampuan komunikasi matematis meningkat 
menjadi lebih baik dan mencapai KKM. Namun kenyataan ini tidak bisa peneliti simpulkan begitu saja, karena suatu penelitian hasilnya harus berdasarkan hasil analisis data. Jadi, kembali lagi pada hasil analisis data yang telah dipaparkan di atas bahwa hasilnya tidak efektif karena hasil $t_{\text {hitung }}(0,302) \leq t_{\text {tabel }}(2,015)$.

Kelas eksperimen 2 merupakan kelas yang menerapkan model pembelajaran Problem Posing. Berdasarkan pengamatan peneliti siswa-siswa di kelas eksperimen 2 mempunyai antusias yang besar pada saat proses pembelajaran. Hal ini juga terlihat dari hasil kemampuan komunikasi matematis siswa melalui nilai rata-rata ulangan harian dalam bentuk soal esai yang mengandung indikator kemampuan komunikasi matematis yang diperoleh dari guru matematika SMP Negeri 47 Batam sebesar 61,511 kemudian setelah mendapatkan perlakuan pembelajaran dengan model Problem Posing meningkat menjadi 74,021 melebihi KKM yaitu 70 yang kemudian dibuktikan melalui uji-t satu sampel. Menurut hasil perhitungan diperoleh hasil $t_{\text {hitung }}(2,366)>t_{\text {tabel }}(2,013)$. Hasil tersebut sekaligus membuktikan bahwa penerapan model pembelajaran Problem Posing efektif terhadap kemampuan komunikasi matematis siswa kelas VII SMP Negeri 47 Batam. Untuk memperkuat hasil penelitian ini maka dibandingkan dengan penelitian yang relevan dilakukan oleh Ernawaty (2010), dengan hasil penelitiannya menunjukkan pembelajaran matematika dengan menggunakan model pembelajaran Problem Posing lebih meningkat dari pembelajaran konvensional. Hasil ini juga senada dengan penelitian yang dilakukan oleh Juano dan Pardjono dimana diperoleh hasil terdapat pengaruh antara pembelajaran problem posing dan direct instruction terhadap kemampuan berpikir kritis dan kemampuan komunikasi matematis dan tidak terdapat interaksi antara strategi pembelajaran dan tingkat kemampuan belajar matematika peserta didik terhadap kemampuan berpikir kritis dan komunikasi matematis (Juano \& Pardjono, 2016). Menurut pendapat Harisantoso (dalam Shoimin, 2016) pengajuan soal juga memberikan kesempatan kepada siswa untuk aktif secara mental, fisik, dan sosial, di samping memberi kesempatan kepada peserta didik untuk menyelidiki dan membuat jawaban yang divergen (mempunyai lebih dari satu jawaban).

Adapun faktor-faktor yang mempengaruhi kemampuan komunikasi matematis menurut Ansari (2016) antara lain sebagai berikut:

1. Pengetahuan prasyarat 
Pengetahuan prasyarat merupakan pengetahuan yang telah dimiliki siswa sebagai akibat proses belajar sebelumnya. Hasil belajar siswa tentu saja bervariasi sesuai kemampuan dari siswa itu sendiri. Jenis kemampuan yang dimiliki oleh siswa tersebut sangat menentukan hasil pembelajaran selanjutnya.

2. Kemampuan Membaca, Diskusi dan Menulis

Komunikasi matematis berdasarkan ketiga aspek yaitu kemampuan membaca, diskusi, dan menulis dapat membantu siswa untuk memperjelas pemikiran mereka dan dapat mempertajam pemahaman. Diskusi dan menulis adalah dua aspek penting dari komunikasi untuk semua level.

\section{Pemahaman Matematis (Mathematical knowledge)}

Pemahaman matematis adalah tingkat atau level pengetahuan siswa tentang konsep, prinsip, algoritma dan kemahiran siswa menggunakan strategi penyelesaian terhadap soal atau masalah yang disajikan.

Setelah melihat keefektifan kemampuan komunikasi matematis siswa dari kedua kelas eksperimen tersebut. Tahapan selanjutnya yaitu melihat perbedaan kemampuan komunikasi matematis siswa antara kelas eksperimen 1 dan kelas eksperimen 2 dengan menggunakan $t$-test polled varians (uji $\mathrm{t}$ dua pihak) hingga diperoleh hasil $-t_{\text {tabel }} \leq t_{\text {hitung }} \leq t_{\text {tabel }}$ sehingga didapat $-1,986 \leq-1,424 \leq 1,986$ hal ini berarti tidak terdapat perbedaan yang signifikan antara model pembelajaran Problem Solving dan Problem Posing terhadap kemampuan komunikasi matematis siswa kelas VII SMP Negeri 47 Batam. Akan tetapi ketika dilihat pada data yang diperoleh rata-rata nilai kemampuan komunikasi matematis dari kelas eksperimen 1 dan kelas eksperimen 2 jauh berbeda yaitu 70,533 dan 74,021. Berdasarkan nilai rata-rata tersebut kelas eksperimen 2 lebih efektif daripada kelas eksperimen 1. Hal ini berarti terdapat perbedaan keefektifan kemampuan komunikasi matematis antara kelas eksperimen 1 dengan kelas eksperimen 2. Namun kenyataan ini tidak bisa peneliti simpulkan begitu saja, karena suatu penelitian hasilnya harus berdasarkan hasil analisis data. Jadi, kembali lagi pada hasil analisis data yang telah dipaparkan di atas bahwa hasilnya $-t_{\text {tabel }} \leq t_{\text {hitung }} \leq t_{\text {tabel }}$ sehingga didapat $-1,986 \leq-1,424 \leq 1,986$ hal ini berarti tidak terdapat perbedaan keefektifan yang signifikan antara model pembelajaran Problem Solving dan Problem Posing terhadap kemampuan komunikasi matematis siswa kelas VII SMP Negeri 47 Batam 
Hal ini terjadi karena kedua model pembelajaran baik model pembelajaran Problem Solving maupun model pembelajaran Problem Posing hampir sama dalam penerapannya. Dalam penerapan model pembelajaran Problem Solving dan Problem Posing memiliki persamaan yaitu siswa dituntut lebih aktif, mandiri dan lebih memiliki sifat percaya diri dalam proses pembelajaran di kelas, sehingga komunikasi antar siswa dapat lebih terjalin dengan baik. Dengan rasa percaya diri dan kemandirian yang dimiliki siswa, maka komunikasi antar siswa dapat lebih berjalan efektif. Biasanya dalam proses pembelajaran konvensional hanya ada beberapa siswa saja yang aktif dan percaya diri, namun pada model pembelajaran Problem Posing semua siswa dalam setiap kelompok berperan dalam proses pembelajaran. Tidak jauh berbeda dengan model pembelajaran Problem Solving, semua siswa juga berperan aktif dalam setiap kelompoknya selama proses pembelajaran berlangsung. Sebagaimana yang diungkapkan oleh Priansa \& Setiani (2015) bahwa pembelajaran pemecahan masalah merupakan pendekatan yang sangat efektif untuk mengajarkan proses-proses berpikir tingkat tinggi, membantu siswa memproses informasi yang telah dimilikinya, dan membangun siswa untuk membangun sendiri pengetahuannya tentang dunia sosial dan fisik di sekelilingnya. Menurut pendapat Harisantoso (dalam Shoimin 2016) pengajuan soal juga memberikan kesempatan kepada siswa untuk aktif secara mental, fisik, dan sosial, di samping memberi kesempatan kepada peserta didik untuk menyelidiki dan membuat jawaban yang divergen (mempunyai lebih dari satu jawaban).

\section{KESIMPULAN}

Berdasarkan hasil penelitian dan pembahasan, maka dapat disimpulkan bahwa Model pembelajaran Problem Solving tidak efektif terhadap kemampuan komunikasi matematis siswa, sedangkan model pembelajaran problem posing efektif terhadap kemampuan komunikasi matematis siswa serta tidak terdapat perbedaan keefektifan yang signifikan antara model pembelajaran problem solving dan problem posing terhadap kemampuan komunikasi matematis siswa kelas VII SMP Negeri 47 Batam.

\section{REFERENSI}

Ansari, B. I. (2016). Komunikasi Matematik, Strategi Berpikir dan Manajemen Belajar, Konsep dan Aplikasi. Aceh: Pena.

Ernawaty. (2010). Upaya Meningkatkan Hasil Belajar Matematika melalui Model Pembelajaran 
Problem Posing pada Pokok Bahasan Bangun Datar Siswa Kelas VII4 SMPN 9 Batam Tahun Pelajaran 2009-2010. Universitas Riau Kepulauan.

Juano, A., \& Pardjono. (2016). Pengaruh pembelajaran Problem Posing terhadap Kemampuan berfikir Kritis dan Komunikasi matematis Siswa Kelas V SD. Prima Edukasia, 4(1), 46-53.

NCTM. (2000). Principles and Standards for School Mathematics. USA.

Priansa, D. J., \& Setiani, A. (2015). Manajemen Peserta Didik dan Model Pembelajaran. bandung: Alfabeta.

Ramdani, Y. (2012). Pengembangan Instrumen Dan Bahan Ajar Untuk Meningkatkan Kemampuan Komunikasi, Penalaran, Dan Koneksi Matematis Dalam Konsep Integral. Jurnal Penelitian Pendidikan, 13(1), 44-52.

Shoimin, A. (2016). 68 Model Pembelajaran Inovatif dalam Kurikulum 2013. Yogyakarta: Arruzz Media.

Suhendri, H., \& Mardalena, T. (n.d.). Pengaruh Model pemelajaran problem solving terhadap hasil belajar. Formatif, 3(2), 105-114.

Sutikno, S. (2014). Metode \& Model-model Pembelajaran. Lombok: Holistica. 